\title{
Pobyt Aleksandry Kołłontaj w Szwecji i Danii (IX 1914-I 1915)
}

\author{
The sojourn of Alexandra Kollontai in Sweden and Denmark \\ (IX 1914-I 1915)
}

The aim of this article is to present the activites undertaken by Alexandra Kollontai during her stay in Sweden in 1914. Alexandra was a famous socialist activist at the time, and as a consequence of her activity had to flee Russia in 1908. For the following eight years, she remained in exile. She traveled throughout Europe, but collaborated most closely the with German Social Democrats party.

After the I World War began, Kollontai - along with her son, Michael - was arrested. Thanks to an intervention of influential German politicians, both of them were released from jail. Shaken, she broke up her ties with the German socialist movement. Alone, Kollontai traveled to Sweden in September 1914, and moved for good to Stockholm.

During the sojourn in Sweden, Kollontai was in touch with one of the most prominent local socialist activists, Hjalmar Branting, and took an active part in the Swedish socialist movement. During her short-term stay in Norway, Kollontai was not formally a supporter of the Bolshevik proposition, but she still wrote letters to Lenin. She also had a love affair with a Bolshevik comrade, Alexander Shliapnikov.

The Swedish police arrested Kollontai for participation in anti-military propaganda activities. She was exiled from the country in November 1914, to Copenhagen. Also there, Kollontai managed to establish close relationship with the Bolsheviks. Hereafter, she has played a crucial role in the re-opening of the northern smuggling route.

Słowa kluczowe: Aleksandra Kołłontaj, Rosja, Szwecja, Dania, propaganda Keywords: Alexandra Kollontai, Russia, Sweden, Denmark, propaganda

Postać Aleksandry Kołłontaj od wielu lat cieszy się niesłabnącą popularnością wśród mieszkańców krajów skandynawskich. Jest ona kojarzona jako przedstawiciel dyplomatyczny ZSRR w Norwegii i Szwecji podczas burzliwych lat międzywojnia i II wojny światowej. 
Zdecydowanie mniej znana jest aktywność Kołłontaj w okresie I wojny światowej gdy przeszła na stronę bolszewików. Wciąż wśród historyków trwa dyskusja w jakich okolicznościach nastąpiła tak radykalna przemiana ze zwolenniczki niemieckiej socjaldemokracji w fanatyczną wyznawczynię idei Lenina. Istotną kwestią pozostaje pytanie czy już podczas swojego pierwszego kilkumiesięcznego pobytu w Szwecji „zwolenniczka wolnej miłości” tworzyła struktury szpiegowskie i kanały przerzutowe pieniędzy dla Lenina.

Niniejszy artykuł nawiązuje do dyskursu historyków na temat roli oraz związków Aleksandry Kołłontaj ze Szwecją. Materiały w językach szwedzkim, norweskim oraz duńskim zostały przetłumaczone przez Emilię Fabisiak oraz Joannę Hald w ramach dotacji celowej na projekt Aktywność Aleksandry Kottontaj (1872-1952) podczas pobytu jako ambasador w Norwegii i Szwecji w pierwszej potowie $X X$ wieku. Pozostałe obcojęzyczne teksty zostały przetłumaczone przez autora.

W przededniu wybuchu I wojny światowej Aleksandra Kołłontaj przebywała w Niemczech. Od 1908 roku, kiedy musiała uciekać z Rosji przed ochrana, lewicowa aktywistka związała się z ruchem socjalistycznym działającym na terenie państwa Wilhelma II. W sierpniu 1914 roku przeżyła jednak szok. Przebywała w Reichstagu, gdy jej niemieccy „towarzysze” zagłosowali za powiększonym budżetem wojskowym, wspierając tym samym działania agresywnej polityki cesarskich elit. Ponadto jeden z deputowanych do parlamentu poprosił córkę carskiego generała, by opuściła budynek, gdyż jako Rosjanka nie powinna tam przebywać. Wieczorem zapisała w swoim dzienniku: „byłam przekonana, że albo oni postradali zmysły albo ja zwariowałam"1.

Wkrótce wśród rosyjskich emigracyjnych, lewicowych środowisk zaczęły się pojawiać oznaki patriotycznego ożywienia, a nawet poparcia dla carskiego reżimu. W taki sposób zachowywał się nawet bliski przyjaciel i mentor, Aleksandry Kołłontaj, Jerzy Plechanow. Zwolenniczka pacyfizmu nie mogła tego zaakceptować i odcięła się od swojego dawnego środowiska².

1 A. M. Kołłontaj, Letopis mojej żyzni, Moskwa 2004, s. 215-217; Z. Szejnis, Put k’ wierszine, Moskwa 1984, s. 35-43.

2 Jerzy Plechanow (1856-1918) - początkowo członek organizacji narodnickich Ziemla i Wola. Prześladowany przez władze rosyjskie od 1880 roku na emigracji w Szwajcarii. Po zapoznaniu się z dziełami Karola Marksa zrezygnował z ideologii narodnickiej na rzecz marksizmu. W 1883 roku założył pierwszą marksistowską organizację rosyjską Wyzwolenie Pracy. W 1903 roku nie poparł bolszewików na drugim zjeździe Socjaldemokratycznej Partii Robotniczej Rosji w Brukseli. W tym czasie, z uwagi na różnice poglądów zarówno w dziedzinie filozofii, jak i polityki, zakończył długoletnią współpracę z Leninem. Był negatywnie nastawiony do przemian w Rosji po 1917 roku. S. Baron, Plekhanov: The Father of Russian Marxism, Stanford 1963; O. Figes, Taniec Nataszy. Z dziejów kultury rosyjskiej, Warszawa 2007, s. 188; G. Pietrow, A. M. Kołtontaj w gody pierwoj mirowoj wojny, Istoria SSSR 1968, No. 3, s. 93-94. 
Wkrótce razem z synem Michałem została aresztowana przez niemiecką prokuraturę pod zarzutem szpiegostwa na rzecz Rosji. Uwolniono ją dzięki wstawiennictwu wpływowych niemieckich socjalistów, którzy udowodnili cesarskim urzędnikom, iż Kołłontaj jako była rewolucjonistka nie mogła służyć caratowi. Natomiast jej syn pozostał nadal uwięziony³.

Aleksandra Kołłontaj miała świadomość, iż musi jak najszybciej opuścić państwo Wilhelma II, pobyt w więzieniu oraz sytuacja syna miała zły wpływ na jej psychikę. Rosyjska emigrantka opuściła Niemcy wraz z synem pod koniec sierpnia 1914 roku. Przez kilka dni przebywali w Kopenhadze. Kołłontaj nawet nie rozważała pozostania w Danii, gdyż tamtejsza partia socjalistyczna była dużo słabsza niż szwedzka. Poprzez Kopenhagę dotarli do Sztokholmu, gdzie zamieszkała w pensjonacie Karlson przy ulicy Birger Jarlsgatan, a jej syn wyjechał do Wielkiej Brytanii ${ }^{4}$.

Wybór miejsca azylu przez Kołłontaj nie był przypadkowy. Przyszła ambasador już jako dziecko jeździła do stolicy monarchii Bernadotte, dzięki czemu poznała język szwedzki. Jako dorosła kobieta szybko - podczas pobytu na emigracji - nawiązała kontakty ze szwedzkimi socjalistami. Podczas kongresu lewicy, który odbył się w Kopenhadze w 1910 roku poznała czołowych działaczy Szwedzkiej Socjaldemokratycznej Partii Pracy (SAP) ${ }^{5}$, Hjalmara Brantinga oraz Zetha Höglunda ${ }^{6}$.

3 J. Briesław, Aleksandra Michałowna Kołtontaj, Moskwa 1974, s. 27; B. Farnsworth, Aleksandra Kollontai: Socialism, Feminism, and the Bolshevik Revolution, Stanford 1980, s. 44-45.

4 K. Hauge, op. cit., s. 31. J. Briesław, op. cit., s. 43; C. Halvorsten, Revolutionens Ambassadør. Alexandra Kollontay liv og devned (Aarene 1872-1917), Kobenhavn 1946, s. 201. Carsten Halvorsten, to pseudonim pod którym Gustaw Johansson opublikował swoje wspomnienia o Aleksandrze Kołłontaj w Danii.

5 Sveriges Socialdemokratiska Arbetareparti - Szwedzka Partia Pracy, potocznie nazywana Socjaldemokraterną powstała w 1889 roku, jej przedstawiciele zasiedli w Riskdagu w 1896 roku. Walczyli o powszechne prawa wyborcze dla mężczyzn i kobiet, co udało się osiągnąć w 1920 roku. Od 1932 roku z krótkimi przerwami partia rządzi Szwecją. K. Dębiec, Fenomen szwedzkiej Socialdemokraterny, http://www.psz.pl/tekst-2241/Krzysztof-Debiec, Fenomen-szwedzkiejSocialdemokraterny [odczyt z dn. 28.09.2013].

6 Hjalmar Branting (1860-1925) - Od 1889 stał się jednym z współtwórców Szwedzkiej Socjaldemokratycznej Partii Robotniczej, a od 1907 jej przywódcą. Redaktor licznych tytułów socjalistycznej prasy. W latach 1917-1918 był ministrem finansów, w 1919 przewodniczącym kongresu II Międzynarodówki w Bernie. Był również uczestnikiem konferencji pokojowej w Paryżu 1919 roku, a także konferencji w Londynie w sprawie Wysp Alandzkich 1920.Wielokrotnie w dwudziestoleciu międzywojennym pełnił funkcję premiera, zaś w latach 1921-1923 ministra spraw zagranicznych. W latach 1922-1925 był członkiem Rady Ligi Narodów. Był też inicjatorem rewizji konstytucji i utworzenia ministerstwa opieki społecznej oraz rzecznikiem respektowania praw małych narodów, oraz zdeklarowanym pacyfistą. Reprezentował poglądy reformistyczne i sprzeciwiał się przewrotowi bolszewickiemu w Rosji. W 1921 roku został laureatem Pokojowej Nagrody Nobla. H. Branting, http://www.nobelprize.org/nobel_prizes/peace/laureates/1921/branting-facts.html 
Rok później Aleksandra Kołłontaj odwiedziła Malmö i wzięła udział w antywojennej demonstracji, zaś w 1912 roku przeszła ulicami Sztokholmu w pierwszomajowej demonstracji. Przyjaciółka Plechanowa pisywała również artykuły do skandynawskiej socjalistycznej prasy. Według ustaleń norweskiego uczonego, Kaare Hauge ich tematyka zamykała się w haśle „dom i prostytucja”.

Należy podkreślić, iż ówczesna sytuacja Szwecji była korzystna dla Kołłontaj. Monarchia Bernadotte przechodziła gruntowną industrializację, której skutkiem był rozwój miast oraz powstanie silnej klasy robotniczej. Stopniowy wzrost znaczenia tej grupy społecznej sprzyjał wzmacnianiu środowisk lewicowych. Natomiast partie liberalne i konserwatywne traciły na popularności. Wciąż utrzymywały się jednak przy władzy dzięki cenzusom majątkowym. Sytuacja ta prowadziła do licznych napięć na scenie politycznej, gdyż społeczeństwo domagało się demokratyzacji kraju

Po wybuchu I wojny światowej bezpartyjny rząd Hjalmara Hammarsjkölda ogłosił neutralność Szwecji, wzmocnioną w grudniu 1914 przez wspólną deklarację władców krajów skandynawskich o niezaangażowaniu ich państw w wojnę. Pomimo tego na monarchię Gustawa V przez cały czas były kierowane naciski, nie tylko ze strony państw centralnych ale również Ententy, a zwłaszcza Rosji. Wprowadzono także powszechną służbę wojskową - co spotkało się z oporem społeczeństwa. Sporą popularność zdobywały hasła pacyfistyczne. Przodowali w niej socjaliści, którzy łączyli kwestię poboru z przyznaniem praw obywatelskich. Odwoływali się także do haseł pacyfistycznych, co musiało odpowiadać Kołłontaj’.

[odczyt z dn. 27.09.2013]; Zeth Höglund (1884-1956) - Jeden z liderów szwedzkiej socjaldemokraci, jednak po rewolucji październikowej poparł bolszewików. Był jednym z założycieli szwedzkiej partii komunistycznej, a od 1919 roku członkiem Kominternu. W połowie lat 20. XX wieku wrócił do socjalistów, ale nie odzyskał dawnej pozycji. Był pacyfistą. Napisał biografię Hjalmara Brantinga. Z. Höglund, http://www.experiencefestival.com/a/Zeth_Hglund_-_Anti-Militarism/ id/5606233 [odczyt z dn. 27.09.2013].

7 C. Porter, Alexandra Kollontai: The Lonely Struggle of the Woman Who Defied Lenin, New York 1980, s. 176, 185; K. Hauge, Alexandra Kollontai - The Scandinavian Period, Minnesota 1971 (nieopublikowany doktorat), s. 24.

${ }_{8} \mathrm{Na}$ początku XX wieku wskutek cenzusów wyborczych zaledwie 9,5\% szwedzkiego społeczeństwa mogło głosować w wyborach. Wpływ na zmiany na scenie politycznej w Szwecji miało również zwiększenie w 1907 roku liczby uprawnionych do udziału w wyborach do 20\%. Często wybuchały konflikty dotyczące liberalizacji prawa wyborczego pomiędzy partiami politycznymi. Zwłaszcza siły lewicowe dążyły do demokratyzacji Izby wyższej Riskdagu, co w 1917 roku doprowadziło do licznych demonstracji i zamieszek w Sztokholmie. Po nich socjaliści dołączyli w rządu koalicyjnego. Pełne prawa wyborcze przyznano mężczyznom dopiero w 1919 roku, zaś kobietom rok później. P. Jeannin, Histoire de pays Scendinaves, Paris 1956, s. 85-97; A. Kersten, Historia Szwecji, Wrocław 1973, s. 345-349; T. Cieślak, Szwecja. Z Dziejów XIX i XX wieku, Poznań 1969, s. 68-70.

9 Hjalmar Hammarskjöld (1862-1952) - Przed rozpoczęciem kariery politycznej był profesorem prawa cywilnego na uniwersytecie Uppsala. Zajmowała się również kwestiami prawa między- 
Pobyt w Szwecji był początkowo zdecydowanie przyjemniejszy niż w Niemczech. 28 sierpnia, Aleksandra Kołłontaj napisała list do swojej wieloletniej przyjaciółki, pisarki i tłumaczki Tatiany Szczepnik-Kupiernik. Swoje ostatnie przeżycia podsumowała następująco: „przeszłam wiele ciężkich i koszmarnych rzeczy”. Wyrażała w nim olbrzymią radość z opuszczenia Niemiec: „radośnie krzyczę jako człowiek wypuszczony z niewoli”10.

Na początku swojego pobytu, Kołłontaj starała się odzyskać równowagę psychiczną po przeżyciach w Niemczech. W kolejnym liście do Szczepnik-Kupiernik z 20 września 1914 roku opisała swoje ówczesne życie oraz przemyślenia na temat państwa, gdzie przyszło jej żyć. Klimat miejsca, gdzie przebywała odbiegał od tępa życia Berlina, z którego pamiętała „bezsenne noce” albo „koszmary”. Pensjonat, w którym zamieszkała był przytulny i utrzymany w starym „stylu lat 40.” XIX wieku, goście rozmowni, mogła dyskutować z nimi o równouprawnieniu kobiet. Według niej Szwecja była krajem spokojnym, gdzie było niezwykle „cicho”, a ludzie „mówią do siebie po imieniu, niczym do przyjaciół, do tego zawsze są gotowi pomóc”. Państwo „zaś wciąż jeszcze żyje w połowie XIX wieku. Jest niezwykle spokojne, życzliwe, jak to bywa u narodu, który jeszcze nie został wyczerpany przez szalony [...] kapitalizm"11.

Atmosfera jakiej codziennie doświadczała przypominała Aleksandrze czasy, kiedy bywała w Szwecji razem z matką. Miała wrażenie, że nic się nie zmieniło. Zachwalała także przed Tatianą tamtejszą kulturę oraz literaturę. Namiętnie chodziła do sztokholmskich teatrów. Warto podkreślić, iż Kołłontaj była zafascynowana skandynawskimi sztukami teatralnymi już wiele lat wcześniej, wspominała o tym w korespondencji z Plechanowem ${ }^{12}$.

narodowego, co spowodowało jego powołanie w 1904 roku do Stałego Trybunału Arbitrażowego. Po upadku konserwatywnego rządu w 1914 roku, spowodowanym wprowadzeniem powszechnej służby wojskowej, został premierem Szwecji. Funkcję pełnił do 1917 roku kiedy powołano koalicyjny rząd konserwatywnego polityki, a wcześniej prezesa Banku Centralnego Carla Swartza. Następnie Hammarskjöld pełnił do swojej śmierci prestiżowe, choć niezbyt wpływowe funkcje, takie jak np. przewodniczący fundacji noblowskiej. Zob.: H. Hammarskjöld http://www.britannica.com/ EBchecked/topic/253598/Hjalmar-Hammarskjold [odczyt z dn. 10.09.2013]; I. Andersson, Dzieje Szwecji, Warszawa 1967, s. 314-315; J. Gilmour, Sweden, the Swastika and Stalin. The Swedish Experience in the Second World War, Edinburg 2012, s. 8-9.

10 Tatiana Szczepkina-Kupiernik (1874-1952) - Znana poetka i pisarka związana z Moskwą. Współpracowała z wieloma rosyjskimi poczytnymi gazetami . Sympatyzowała z ruchem feministycznym przed I wojną światową. Po rewolucji październikowej 1917 roku zajęła się tłumaczeniem zagranicznych sztuk. Praskowia Arian (1865-1944) - publicystka i redaktorka kobiecych pism. T. L. Szczepkina-Kupiernik, Dni mojej Żyzni, Moskwa 1950; A. M. Kołłontaj, „Riewoljucija-wielikja mjatieżnica..." Izbrannoje pisma 1901-1952, Moskwa 1988, s. 113.

11 Eadem, „Riewoljucija-wielikja mjatieżnica...” Izbrannoje..., s. 115.

12 Ibidem, s. 115. 
Obraz spokojnego życia przedstawiony przez Kołłontaj nie odzwierciedlał jej całej aktywności. Wkrótce po przybyciu ponowiła ona współpracę ze szwedzkimi socjalistami, którzy starali się ją uhonorować. Skandynawscy lewicowcy umożliwili jej także publikowanie tekstów w swojej prasie. Zorganizowali następnie córce carskiego generała oraz działaczowi partii bolszewickiej Aleksandrowi Szlapownikowi tournée, w trakcie którego propagowali pacyfizm. Rychło lewicowych działaczy z Rosji połączył romans ${ }^{13}$.

Aleksandra Kołłontaj starała się również uczestniczyć w życiu intelektualnym i politycznym szwedzkiej socjaldemokracji. Pracowała w redakcji pisma „Försvarsnihilisten”, a także opublikowała artykuł Wojna i nasze najbliższe cele, który prezentował jej poglądy na temat trwającej wojny. Odwołała się w nim do postanowień Nadzwyczajnego Międzynarodowego Socjalistycznego Kongresu w Bazylei z 1912 roku, na którym ustalono pacyfistyczną linię lewicy. Skrytykowała w nim środowisko II Międzynarodówki, która według autorki wspierało w zbyt małym stopniu ideę internacjonalizmu robotniczego: „jeśli solidarność łączyłaby wszystkich robotników oraz istniała rzeczywista jedność [ich] celów, klasa robotnicza nie musiałaby się obawiać krwawych wojen. Stary, kapitalistyczny imperializm i zastraszone burżuazyjne społeczeństwo" nie odważyliby się wystąpić w obliczu „czerwonego widma”. Niestety, zdaniem córki carskiego generała, socjaliści w wielu krajach okazali się zbytnimi „szowinistami”, którzy uwierzyli w propagandę walczących mocarstw. Kołłontaj nie miała złudzeń, że „Niemcy podnoszą miecz [...], by wyeliminować cara" 14 .

Następnie przyjaciółka Lenina poruszyła kwestię efektów trwającej wojny. Według niej zagrożona została nie tylko kultura, lecz również przyroda: „czy to nie z powodu wojny, wspaniałe stare puszcze są bezwzględnie niszczone (Na przykład,

13 Aleksander Szlapownikow (1885-1937) - Inżynier i działacz partii bolszewickiej. W 1918 roku był komisarzem pracy. Od 1919 roku do 1922 roku stał na czele opozycji robotniczej, frakcji partii bolszewickiej, która sprzeciwiała się polityce Lenina względem robotników. Zginął w okresie wielkich czystek. http://www.hrono.ru/biograf/bio_sh/shljapnikov_ag.php [odczyt z dn. 17.09.2013]; E. Clements, Bolshevik Feminist: The Life of Alexandra Kollontai, Indiana 1979, s. 86; M. Futrell. Northern Underground. Episodes of Russian Revolutionary Transport and Communications through Scandinavia and Finland. 1863-1917, London 1963, s. 87; K. Hauge, op. cit., s. 29-30.

14 Försvarsnihilisten było lewicowym pismem wydawanym w 1914 roku przez szwedzkich marksistów. Występowali przeciwko I wojnie światowej krytykowali stosunki społeczne w monarchii Bernadotte. Redaktorami byli Einar Ljungberg i Axel Holmström; A. Kołłontaj, The War and Our Immediate Tasks, [w:] A. Kollontai, Selected Articles and Speeches, New York 1984. Cytowana praca zamieszczona jest na stronie http://www.marxists.org/archive/kollonta/1914/wartime.htm (29.09.2013). Z uwagi na brak numeracji stron przypisy nie będą wyposażone w numery stron;

Försvarsnihilisten" http://www.worldcat.org/title/forsvarsnihilisten-kamp-mot-militarismen-i-alladess-former/oclc/186555779; http://runeberg.org/tiden/1915/0181.html [odczyt z dn. 29.09.2013]. 
lasy na obrzeżach Paryża [...])? Czy to nie jest wojna, która niszczy najpiękniejsze i najcenniejsze zabytki oraz dzieła sztuki ?'5".

Według Kołłontaj efekty społeczne starcia mocarstw także będą straszne: „Chaos i nędza będą niepodzielnie panowały po tej wojnie światowej, nawet wśród zwycięskich krajów. Widoczny będzie wzrost liczby osób niezdolnych do pracy: inwalidów, obłąkanych i sierot”. Następnie rozpocząłby się olbrzymi kryzys gospodarczy, zaś repatriacje od przegranych nie uzdrowiłyby sytuacji, a jedynie wzmocniłyby kapitalistów oraz imperialistów. Jedynym wyjściem z tej koszmarnej sytuacji byłoby zjednoczenie środowisk socjalistycznych wokół idei pacyfistycznych oraz zwalczanie szowinizmu, a także militaryzmu ${ }^{16}$.

Aleksandra Kołłontaj skierowała swoją ostrą krytykę wobec środowisk lewicowych, krytykowała jednak imperialistyczna politykę wielkich mocarstw. Warto również zaznaczyć, iż w ogóle nie odnosiła się do sytuacji Szwecji. Prawdopodobnie nie chciała sprawiać problemów swoim przyjaciołom ze Szwedzkiej Partii Pracy. Warto podkreślić, iż wyrażali oni zbliżone do niej antymilitarystyczne poglądy na łamach prasy. Koncepcja szeroko zakrojonej współpracy z różnymi środowiskami lewicowymi przyszła ambasadorka traktowała poważnie. Świadczy o tym jej ówczesna korespondencja z Leninem, w którym negowała jego koncepcję zwartej, silnej partii robotniczej oraz postulowała stworzenie „hasła, które zjednoczyłoby nas wszystkich [socjalistów]"17.

12 listopada 1914 roku o szóstej rano policja wkroczyła do pensjonatu Karlson. Celem funkcjonariuszy Polis było aresztowanie Aleksandry Kołłontaj. Szwedzki dziennikarz i znajomy przyszłej ambasador z lat 30. i 40. XX wieku Gustaw Johansson po latach barwnie opisał tę scenę:

„W porze, którą policje na całym świecie wybrały sobie na przeszukanie mieszkań - policja zapukała do drzwi pokoju hotelowego. Sposób pukania też był typowy dla funkcjonariuszy różnych krajów. Aleksandra Kołłontaj od razu widziała, o co chodzi. Niezbędne było szybkie działanie. Pod poduszką leżały adresy i ważne materiały. Gdyby wpadły w ręce władz, mogłyby w poważny sposób zakłócić działalność kurierów. Żandarmi czekali przed drzwiami, podczas gdy ona ubierała się i chowała papiery pod ubraniem [...].

Podczas, gdy Aleksandra Kołłontaj protestowała przeciwko naruszeniu jej praw i żądała, by poinformować Brantinga [...], jej mózg pracował na pełnych obrotach próbując wymyślić, jak pozbyć się dokumentów, nim dojdzie do rewizji osobistej.

\footnotetext{
15 A. Kołłontaj, The War and...

16 A. Kołłontaj, The War and...

17 C. Halvorsten, op. cit., s. 207.
} 
Udało się. Pozwolono jej wyjść do toalety. Ale papiery nie mogły ulec zniszczeniu, musiały w ten, czy inny sposób zostać przekazane towarzyszom. Wcisnęła je pomiędzy cysternę klozetu i sufit. Gdy opuszczała hotel w towarzystwie policji, na korytarzu pojawił się inny Rosjanin. Szepnęła szybko:

- Szukaj w toalecie.

Ale nie użyła zwykłego rosyjskiego słowa na toaletę - mogło się zdarzyć, że jeden z funkcjonariuszy znał rosyjski. Użyła [...] wulgarnej nazwy, którą towarzysz od razu zrozumiał.

Funkcjonariusze zbesztali ją:

— Proszę nie rozmawiać po rosyjsku.

Nie musiała. Osiągnęła to, co zamierzała. Po odejściu policji papiery zostały odzyskane. Konspiracyjna działalność na rzecz rewolucji rosyjskiej mogła być kontynuowana pomimo nieobecności Aleksandry" ${ }^{\prime 18}$.

Wyrażona przez Gustawa Johannsona teza, o trwającej już wtedy współpracy Kołłontaj z bolszewikami jest wątpliwa. Pod wpływem Szlapnikowa oraz pacyfizmu deklarowanego przez Lenina lewicowa aktywistka, zaczęła zbliżać się do ich partii. W październiku 1914 zaczęła korespondować z przywódcą odłamu SDPRR. Być może dlatego chciała ukryć niewygodną korespondencje z innymi działaczami rosyjskiej i skandynawskiej lewicy. Szwedzki biograf Kołłontaj twierdził, iż już wtedy: „byli [ze Szplapnikowem] czołowymi koordynatorami nielegalnych łącz informacyjnych wiodących przez Skandynawię". Pokój zwolenniczki wolnej miłości miał być wręcz „sztabem” rosyjskich rewolucjonistów w Szwecji. Natomiast angielski historyk Michael Futrell stwierdził, iż w tym czasie dawna przyjaciółka Plechanowa starała się unikać nielegalnej działalności, aby nie zostać wydaloną z kraju w którym się schroniła. Podobną opinię sformułował Kaare Hauge. Prawdopodobnie kontaktowała się nieoficjalnie z działaczami rosyjskiej emigracji, ale wynikało to ze strachu przed ochrana. Na pewno nie mogła ona wtedy przewozić niemieckich funduszy do Rosji, gdyż administracja Wilhelma II nie zawarła jeszcze porozumienia z emisariuszami Lenina. Koncepcję szwedzkiego biografa Koł-

${ }^{18}$ Rosyjski historyk Michaił Trusz w swojej popularnonaukowej biografii Aleksandry Kołłontaj zastanawiał się jakiego wulgarnego słowa mogła użyć na określenie toalety. Według niego mogło to być słowo uborrnaja często wykorzystywane przez Rosjan fińskiego pochodzenia. Matka przyjaciółki Lenina pochodziła z Finlandii. C. Halvorsten, op. cit., s. 202; M. Trusz, Ot politiki riewoljucionnoj borby i pobiedam na diplomaticzieskim frontier. Żizniennyj put' Aleksandry Kołtontaj "Zototaja wietw' diptomatii Rossii”, Moskwa 2013, s. 58. 
łontaj obala również fakt przytaczany przez niego samego. Przyjaciółka SzczepnikKupiernik spotykała się ze większością osób w miejscach publicznych, zwłaszcza w jej pensjonacie, nie martwiąc się o jakąkolwiek konspirację. Koncepcji Johanssona przeczy również list przywódcy bolszewików do Aleksandra Szlapnikowa z 28 listopada 1914 roku. Kiedy na wieść o aresztowaniach lewicowych działaczy w monarchii Bernadotte Lenin zaklinał adresata, by ten ze „wszystkich sił starał się o nawiązanie kontaktów w Pitrze” przez Sztokholm, czyli stworzył siatkę szpiegowską SDPRR(b) działającą w krajach skandynawskich. W tym czasie Kołłontaj przebywała już poza Szwecją ${ }^{19}$.

W swoich wspomnieniach po latach Aleksandra Kołłontaj skomentowała lakonicznie te wydarzenia: „Pisałam i działałam [w Szwecji] do tego momentu, kiedy szwedzki konserwatywny rząd Hammarjskjolda postanowił zlikwidować «bolszewicki ośrodek». Aresztowali mnie, zamknęli w więzieniu [...] i wyrzucili z kraju”"20.

Aleksandra Kołłontaj pisała o „bolszewickim ośrodku”. Należy jednak pamiętać, iż jej wspomnienia powstały w połowie lat 20. XX wieku, ukazując się zresztą początkowo w zachodnich pismach i wydawnictwach. W tym czasie ówczesna przedstawicielka dyplomatyczna ZSRR w Norwegii musiała podtrzymywać mit jedności bolszewików jeszcze przed 1914 rokiem ${ }^{21}$.

Początkowo nie było wiadomo, gdzie została uwięziona Aleksandra Kołłontaj. Według jej przyjaciółki, Ines de Palenci, rosyjska rewolucjonistka miała uzyskać widzenie z pastorem. Zapytała go o jego światopogląd. Po krótkiej dyskusji, stwierdził, iż jako dobry chrześcijanin nie może odmówić jej pomocy. Wkrótce przekazał złe wieści Brantingowi ${ }^{22}$.

Wkrótce Hjalmar Branting uzyskał możliwość spotkań z Kołłontaj w więzieniu Kungsholm, a później w Malmö, gdzie ją przewieziono. Początkowo szwedzkie władze chciały wydać lewicową działaczkę rosyjskim władzom, ale po protestach socjaldemokratów została pod koniec listopada 1914 roku wysłana do Kopenhagi.

19 A. M. Kołłontaj, Letopis..., s. 221-222; M. Futrell, op. cit., s. 87; C. Halvorsten, op. cit., s. 201; Odpowiedź Włodzimierza Lenina z przełomu listopada/grudnia 1914 roku na nieopublikowany list Aleksandry Kołłontaj. Rosyjska socjalistka musiała napisać swój list przed aresztowaniem. We wspomnieniach utrzymywała, że było to jej pierwsze pismo skierowane do przywódcy bolszewików. W. Lenin, Dzieła Wszystkie. Listy sierpień 1914-październik 1917, Warszawa 1989, t. 49, s. 37; A. M. Kołłontaj, I z moej żyzni i raboty. Wospominaja i Pniewniki, Moskwa 1974, s. 172.

20 A. M. Kołłontaj, Letopis..., s. 222.

21 R. A. Popowkina, Priedistowie, [w:] A. M. Kołłontaj, Letopis..., s. 5-6.

22 Ines de Palencia (1876-1974), wł. Isabel Oyzarbal Smith. Hiszpańska dziennikarka związana z Meksykiem. W latach 30. XX wieku reprezentowała Hiszpanię w komisji Ligii Narodów do spraw niewolnictwa. Po wojnie domowej w Hiszpanii wyjechała do Meksyku. http://www.andalucia.cc/viva/mujer/aavmalag.html\#Oyarzabal [odczyt z dn. 15.10.2013]; I. De Palencia, Alexandra Kollontay, ambassadress from Russia, New York 1947, s. 71. 
Kołłontaj jeszcze na terenie monarchii Bernadotte wysłała telegram do działaczy Szwedzkiej Partii Pracy: „Wyzwolona z więzienia w Mälmo posyłam swoje pozdrowienia dla [was]"23.

Po aresztowaniu, szwedzka prawicowa prasa, zwłaszcza pisma „Nya Dagligt Allehanda” i „Stockholms Dagblad” rozpoczęły kampanię informacyjną wymierzoną w Rosjankę. W pierwszym z tytułów można było przeczytać: „Gdy obcokrajowiec z przeszłością taką, jak pani Kołłontaj - wydalono ją zarówno z Rosji, jak i Niemiec - dziękuje za gościnność, z której korzysta w innym kraju, mieszając się do jego wewnętrznych spraw, należy nazwać takie zachowanie bezczelnym”"24.

Dziennikarze próbowali udowodnić, iż była ona rosyjskim szpiegiem. Świadczyć o tym miała chociażby mapa ojczyzny Henrika Ibsena, której według redaktorów sztokholmskich dzienników, używano podczas antyrządowych demonstracji. Teksty prawicowej prasy były również wymierzone w przywódców Szwedzkiej Partii Pracy ${ }^{25}$.

Natomiast socjaliści na łamach swoich organów prasowych oraz podczas wystąpień w Riksdagu udowadniali, iż Kołłontaj nie robiła nic złego. Hjalmar Branting napisał w odpowiedzi prawicowym publicystom: „Najpierw źródła, które z daleka cuchną metodami detektywistycznymi reżimu z czasów Stendahla, relacjonują pobyt naszej towarzyszki w pensjonacie w Sztokholmie, gdzie zamieszkiwała. Przyjmowała tam liczne wizyty towarzyszy partyjnych, a na ścianie najwyraźniej znaleziono mapę Szwecji, 'która pewnikiem była używana na demonstracjach!' Podejrzenie o szpiegostwo [...] jest absurdalne"26.

Sprawa zatrzymania i późniejszej ekstradycji Aleksandry Kołłontaj wywołała olbrzymią dyskusję w szwedzkim społeczeństwie. Lewica próbowała się dowiedzieć jakie były motywy tej decyzji. Dyskutowano o tym nawet na forum Riksdagu, a relacje pojawiały się w regionalnej prasie. W końcu minister spraw wewnętrznych Szwecji Oscar von Sydow ${ }^{27}$ oskarżył lewicową działaczkę o to, iż uprawiała antypaństwową propagandę oraz dobrowolnie nie chciała wyjechać do Rosji. Dowodem na antymilitarną propagandę było jeden akapit w piśmie „Försvarsnihilisten”: „Żałosne państwo kapitalistyczne chronione jest przez trój-

23 K. Hauge, op. cit., s. 31.

24 Cyt za. C. Halvorsten, op. cit., s. 205.

25 Ibidem, s. 206-208.

26 Cyt. za ibidem, s. 205.

27 Oskar von Sydow (1873-1936) Szwedzki polityk pełniący w latach 1914-1917 funkcję ministra spraw wewnętrznych. W 1921 roku przez kilka miesięcy był premierem. Później do śmierci zasiadał w królewskim sądzie najwyższym. Vide: O. von Sydow, http://runeberg.org/nfcg/0740. html [odczyt z dn. 17.09.2013]. 
cę: koronę, krzyż i bagnet. Zwalczając militaryzm, otwieramy drogę dla rewolucji, która uwolni ludzkość od reakcyjnych instytucji, które obecnie blokują drogę do dobrobytu i szczęścia ludu”. Nie udowodniono, że rosyjska emigrantka napisała te słowa. Została jedynie wymieniona w stopce redakcyjnej tego numeru, zaś w już przytaczanym jej artykule zatytułowanym Wojna i nasze najbliższe cele nie było treści rewolucyjnych tylko pacyfistyczne. Do tego publikacja pisma nie została wstrzymana przez cenzurę ${ }^{28}$.

Już ówcześni lewicowi działacze wątpili w argumentację rządu dotyczącą rozpowszechniania przez Kołłontaj antymilitarnej propagandy. Wskazywali, że lewicowej aktywistce nie udowodniono winy. Debata na ten temat ciągnęła się jeszcze długo w szwedzkim społeczeństwie. Przyszła ambasador także zastanawiała się nad przyczynami jej aresztowania.

W trakcie przymusowego pobytu w Kopenhadze, Kołłontaj zastanawiała się nad tymi wydarzeniami. Prawdopodobnie krótki pobyt w więzieniu był dla niej równie traumatyczny jak poprzedni. Wiele lat później, kiedy wracała do Szwecji jak potpred, odczuwała olbrzymią satysfakcję pokazując paszport dyplomatyczny pogranicznikowi. Jedną z pierwszych rzeczy jakie zrobiła w Sztokholmie była wizyta w więzieniu, gdzie ją przetrzymywano ${ }^{29}$.

W liście do Lenina z przełomu listopada/grudnia 1914 roku Kołłontaj opisała ostatnie wydarzenia. Nie ujawniała swoich emocji, starała się przedstawić całą sytuację w analityczny sposób. Ukazała przywódcy bolszewików oficjalne powody swojego aresztowania i ekstradycji, jednak nie wierzyła w nie. Nie napisała wprost jakie ma podejrzenia, gdyż ówczesna korespondencja dawnej przyjaciółki Plechanowa była kontrolowana przez duńską policję. Przyszła ambasador sugerowała, jednak, iż mogą stać za tym Rosjanie. Przedstawiła również wodzowi SDPRR(b) charakterystykę Brantinga. Podkreślała swoją dozgonną wdzięczność liderowi socjaldemokraterny za pomoc i obronę przed „konserwatywną prasą”, aczkolwiek podkreślała, że był typowym socjaldemokratą. Zwracała uwagę, iż poseł do Riksdagu miał patriotyczne poglądy przez co nie mógł całkowicie poświęcić się idei rewolucji. Rosyjska rewolucjonistka podejrzewała, że jego cel stanowiło zdobycie teki ministra. Innych działaczy Szwedzkiej Partii Pracy podsumowała w następujący sposób: „szwedzcy towarzysze postąpili tak, jak przystało towarzyszom”30.

${ }^{28}$ C. Halvorsten, op. cit., s. 209; A. Kołłontaj, The War and Our Immediate Tasks..., Rysk sympatii för Norska apfapnare, Dalpilen 1915, nr 46, s. 1.

29 Po wielu latach, prawdopodobnie za Aleksandrą Kołłontaj, opinię o naciskach Cesarstwa Rosyjskiego na szwedzki rząd powtórzyła Isabel De Palencia. A. M, Kołłontaj, Dipłomaticzieskie Dniewniki. 1922-1940, Moskwa 2001, s. 49; I. De Palencia, op. cit., s. 71.

30 Eadem, „Riewoljucija-wielikja mjatieżnica...” Izbrannoje..., s. 116-118. 
Aleksandra Kołłontaj zwierzyła się także ze swoich wniosków natury politycznej, do których doprowadziła ta sytuacja: „Przy obecnym kryzysie międzynarodówki oraz przy napiętych stosunkach pomiędzy rządami szwedzkim i rosyjskim takie sytuacje [jak moja] są nieuniknione" ${ }^{31}$.

Powyższy fragment listu do Lenina, świadczy, iż Aleksandra Kołłontaj postanowiła silniej związać się z bolszewikami, gdyż po doświadczeniach z ostatnich miesięcy zrozumiała, że pozostawanie samodzielnym działaczem politycznym nie było możliwe. W dobie kryzysu jedności ruchu socjalistycznego wywołanego wojną oraz działań mocarstw dawna przyjaciółka Plechanowa sądziła, że należy przyłączyć się do silnej, wiernej swym ideom grupy. Partii potrafiącej, nawet w nielegalny sposób, bronić swoich członków. Demokratyczne sposoby działania, Brantinga okazały się według niej nieskuteczne.

W innych listach z tego okresu, napisanych do syna i Tatiany Szczepnik-Kupiernik, Kołłontaj ukazała swoje emocje. W korespondencji z Michałem Kołłontajem podkreśliła, że pobyt w szwedzkim więzieniu był dla niej ciężkim przeżyciem, twierdziła, że szwedzkie społeczeństwo nie było winne jej krzywd. Podejrzewała również, iż „aresztowali mnie za to, że jako Rosjanka ośmieliłam się wziąć udział w ich [szwedzkim] życiu politycznym" ${ }^{2}$.

W liście do Hjalmara Brantinga Kołłontaj napisała: ,jeszcze raz przyjmijcie moje gorące podziękowania za przyjacielskie potraktowanie, które zawdzięczam wam i innym szwedzkim towarzyszom. [...] Tylko w podobnych sytuacjach poznaje się prawdziwy narodowy charakter [...]. Mogłam poczuć waszą kulturę i dobre [...] serce. [...] Po całej tej sytuacji jeszcze bardziej będę ceniła wasz naród”. Następnie wyraziła przypuszczenie, iż za całą sytuacją może stać Rosja albo inne europejskie mocarstwo, Niemcy. Zwolenniczka Lenina obiecała, że opisze całą tę sytuację w socjalistycznej prasie i poświęci „maleńki artykuł” swoim obrońcom ${ }^{33}$.

Do dzisiaj nie wiadomo jakie były przyczyny aresztowania Aleksandry Kołłontaj. Według ówczesnych bohaterów i świadków tych wydarzeń istnieją w sumie trzy możliwości: naciski na rząd Hammarskjolda ze strony Niemiec, niechęć imperium carów do rosyjskiej emigracji (nie tylko późniejsza komisarz spraw ludowych została deportowana) działającej w krajach skandynawskich bądź strach szwedzkich władz przed zagranicznymi aktywistami mogącymi sprawiać liczne problemy, krajowi walczącemu o zachowanie neutralności podczas I wojny światowej.

31 Ibidem, s. 118 .

32 Ibidem, s. 118-120.

33 Ibidem, s. 119; Należy podkreślić, że Aleksandra Kołłontaj napisała ten list po francusku. Nie wiadomo jaka była tego przyczyna. Zdjęcie tego tekstu znajduje się w: M. Futrell, op. cit., s. 94-95. 
Nie ma żadnych zachowanych dowodów na dyplomatyczne interwencje zachodnich mocarstw w kwestii Kołłontaj, jednak nie można ich całkowicie odrzucić. Bardziej prawdopodobny była jednak inicjatywa szwedzkich władz, które obawiały się aktywności politycznej rosyjskich emigrantów. Zdecydowali się na ich ekstradycję, zanim zagraniczni socjaliści zdążyliby zirytować państwo Mikołaja II ${ }^{34}$.

W styczniu 1915 roku Aleksandra Kołłontaj opuściła Kopenhagę, którą określała w listach mianem „zimnej jamy”. Przybyła do Norwegii, gdzie stworzyła kanały łączności przebiegające przez kraje skandynawskie do Rosji, którym bolszewicy przewozili pieniądze niemieckiego wywiadu oraz rozkazy Lenina. Wkrótce napisała w swoim dzienniku: „Stoi przede mną ogromne zadanie do wykonania. [...] Pracuję nad tym, aby przekonać i zmobilizować moich norweskich przyjaciół, by poszli bolszewicką drogą. Im jaśniejsza dla mnie jest ta droga, z tym większym zapałem pragnę pozyskać tutejszą lewicę, aby uznała nasze sformułowania (tzn. idee Lenina)" 35 .

Zaledwie kilkumiesięczny pobyt Aleksandry Kołłontaj w Szwecji podczas I wojny światowej był momentem zwrotnym w jej życiu. Lewicowa aktywistka po traumie uwięzienia w Niemczech oraz zerwaniu ze swoim dawnym, socjaldemokratycznym środowiskiem, udała się do skandynawskiego kraju, który znała. Szybko nawiązała współpracę z rosyjską emigracją oraz czołowymi działaczami Szwedzkiej Partii Pracy. Autorka Wasylissy postulowała zjednoczenie środowisk lewicowych. Sądziła, iż będzie mogła uwolnić się od swojej przeszłości i wojennej zawieruchy.

Niestety, nie wszystko rozwinęło się taka jak chciała Aleksandra Kołłontaj. Wkrótce pod zarzutami pacyfistycznej i antypaństwowej działalności została aresztowana, chociaż wiele wskazuje, iż była niewinna.

W swoim tragicznym położeniu Kołłontaj nawiązała współpracę z bolszewikami, jednak wyrażała wątpliwości co do ich koncepcji. Dopiero szwedzkie doświadczenia sprawiły, iż związała się z partią Lenina bez względu na koszty, a następnie zaczęła zatracać w fanatyzmie i uwielbieniu dla męża Nadieżdy Krupskiej. Wyjechała do Norwegii, gdzie stworzyła siatkę wywiadowczą służącą swoim nowym mocodawcom.

34 Ibidem, s. 87-88.

35 A. M. Kołłontaj, I z moej żyzni i raboty..., s. 183. A. K. Kiełbasiewicz, Aleksandra Kołtontaj w Norwegii, „Historia i Polityka” 2009, nr 1, s. 108. 